\title{
培養肝細胞におけるプロトロンビン分泌の制御
}

\author{
伴野 雅洋* 上山 護* 浦山 功* 浅田 敏雄*
}

\section{The control of prothrombin secretion in culture liver cells}

\author{
Masahiro TOMONO*, Mamoru UEYAMA*, \\ Tsutomu URAYAMA* and Toshio ASADA*
}

Key words: vitamin k, calcium, prothrombin, liver cell

\begin{abstract}
Vitamin $\mathrm{K}$ brings calcium flux as well as $\gamma$-carboxylation in liver cells. Prothrombin in creased in the medium of the guinea pig liver cell culture along with the rise of intracellulr $\mathrm{Ca}^{+}$by vitamin $\mathrm{K}$ stimulation. This result indicates a secretion mechanism linked to some chemical stimulations. Pregnane-diol and oleic acid had no effect on the $\mathrm{Ca}^{2+}$ flux but suppressed the prothrombin secretion induced by vitamin $\mathrm{K}$ stimulation, although the inhibition mechanism unknown.
\end{abstract}

\section{は じめに}

ビタミンKは肝細胞に括けるプロトロンビン などの 血液凝固因子 産生に招いて $\gamma$ 一カルボキ シレーションに関与する以外に, 細胞質内 $\mathrm{Ca}^{+}$ 濃度変化を介して生理作用を有していると考兄 られる1) 4).著者らはビタミン $\mathrm{K}$ 刺激を培養細 胞に加光た時の 細胞質内 $\mathrm{Ca}^{+}$濃度変化と培地 中へのプロトロンビン分泌が連動しているかど らか調べた。また分泌機構に対する影響物質の
検討も行なった。

\section{I. 材料と方法}

1 ) 肝細胞懸濁液の作製と 細胞質内 $\mathrm{Ca}^{+}$濃 度測定 : モルモット肝細胞飞 $\mathrm{Ca}^{+}$螢光 指示薬 quin-2を $40 \mu \mathrm{M}$ 取り込ませ, emission 339 $\mathrm{mm}$, exitation $492 \mathrm{~nm}$ でいろいろな濃度のビタ ミン $\mathrm{K}_{1}$ 刺激を加えた時の 螢光变化を 測定し $た^{6) 7)}$.

2 ）培地中プロトロンビン測定のための

* 東邦大学医学部生化学 [干143 東京都大田区大森西 6-11-1], Department of Biochemistry, Toho University School of Medicine, Tokyo, Japan.

** 同 産婦入科, The First Department of Obstetrics and Gynecology, Toho University School of Medicine, Tokyo, Japan. 受付: 1988. 1. 10. 受理 : 1988. 8. 23. 


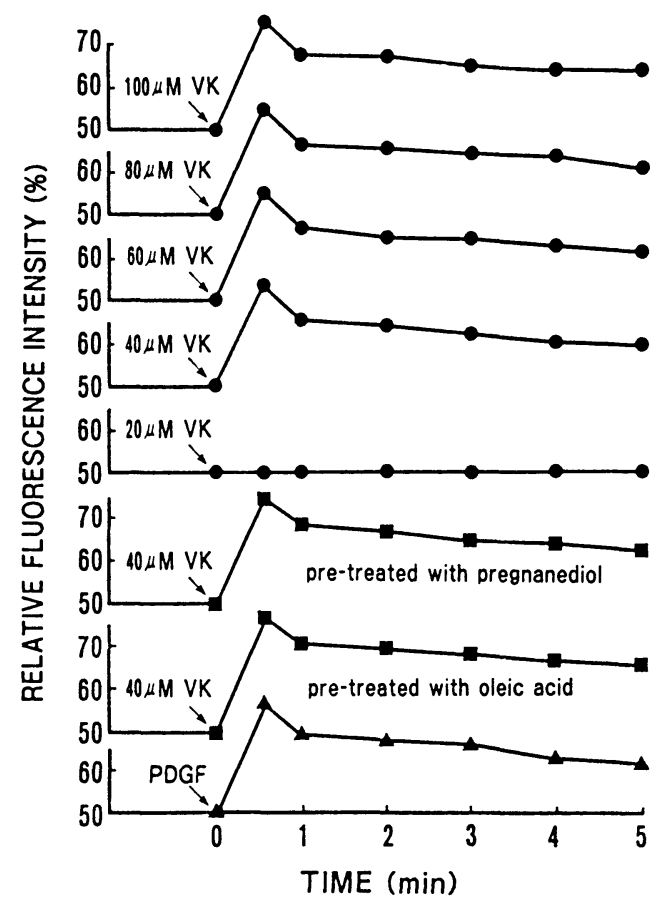

Fig. 1 Intracellular $\mathrm{Ca}^{2+}$ Response

ELISA 法の確立：抗ヒトプロトロンビンを 96 穴プレートの各 well に入れ, PBST で洗って から，モルモット肝細胞懸濁液にビタミン $\mathrm{K}_{1}$ などを添加した後の培地液を抗原として加觉 た。 また前もって第 1 抗体として抗ヒトプロト ロンビン，第 2 抗体としてアルカリフォスファ ターゼ標識抗ヤギ IgGを $1: 1$ で混ぜたものを 加光, 最後に $1 \mathrm{mg} / \mathrm{ml}$ の p-nitrophenylphosphate を加えて，405 nm で吸光度を測定した。 この時ヒト正常血漿のプロトロンビン值を 1 と して standarization を行なった。

\section{II. 結 果}

1）ビタミン $\mathrm{K}_{1} 40 \mu \mathrm{M}$ 以上の刺激でモルモ ット肝細胞質内 $\mathrm{Ca}^{+}$濃度上昇がみられた。 ま たオレイン酸和よび pregnane-diol はこれに対 し全く影響を扣よぼさなかった（図 1 ）。

2) ビタミン $\mathrm{K}_{1}$ 無添加ではモルモット肝細 胞培地中に平均 $0.73 \times 10^{-4}$ のプロトロンビン しか検出されなかったが，ビタミン $\mathrm{K}_{1} 100 \mu \mathrm{M}$ 刺激では $9.85 \times 10^{-4}$ のプロトロンビンが検出

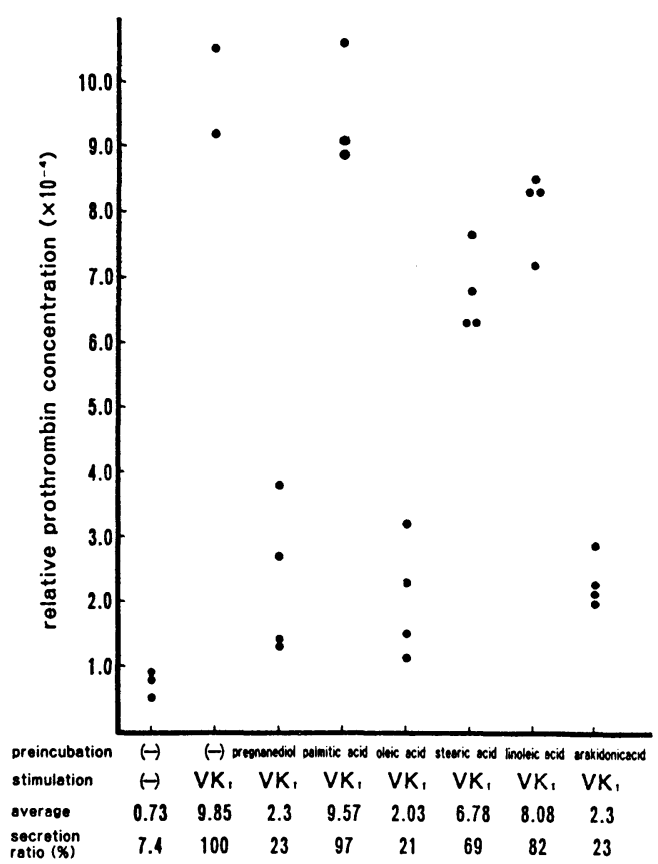

Fig. 2 Prothrombin secretion in guinea pig liver cells

された. pregnane-diol $0.25 \mathrm{mM}$ オレイン酸 $10 \mu \mathrm{M}$, アラキドン酸 $10 \mu \mathrm{M}$ で $37^{\circ} \mathrm{C}, 30$ 分 間前処置した場合はビタミン $\mathrm{K}_{1}$ 単独の時を 100 \%として扮の括の $23 \% ， 21 \% ， 23 \%$ と培地中 へのプロトロンビン分泌阻害がみられた。しか しパルミチン酸ではほとんど阻害はみられず, ステアリン酸, リノール酸でも多少の阻害はみ られたがその割合は小さかった（図 2 ）。

\section{III. 考察}

モルモット肝細胞質内 $\mathrm{Ca}^{+}$濃度上昇に連動 してプロトロンビンが培地中に増量することは ビタミンKによる外来刺激応答性の分泌機構が 肝細胞内で働いている可能性を示している。ビ タミン $\mathrm{K}_{1} 40 \mu \mathrm{M}$ といら濃度は生理的にはか なり高いものであり，これがそのまま主体内で の現象を反映しているとは限らないが少なくと も分泌応答性が存在することは言える。オレイ ン酸や pregnane-diol が肝細胞質内 $\mathrm{Ca}^{*}$ 濃度 上昇は阻害しないが，プロトロンビンの培地中 への放出は抑制するという結果からこれらの物 
$19: 646$

質が分泌反応のいずれかの過程に対して阻害的 に働いていると考兄られる。しかしその機構解 析は今後の検討課題である.

\section{文献}

1) Dimonte D., Bellomo, G., Thor, H., Nicotera, P., Orrenius, S.: Menadione-induced cytotoxicity is asociated with thiol oxidation and alteration in intracellular $\mathrm{Ca}^{2+}$ homeostasis. Arch. Biochem. Biophys., 235:343 350, 1984.

2) Gallin, J.I., Seligmann, B.E., Cramer, E.B., Schiffman, E., Fletcher, M.P.: Effects of vitamin $\mathrm{K}$ on human neutrophil function. $\mathrm{J}$. Immunol., 128: 1399 1408, 1982.

3) Bellomo, G., Mirabelli, F., Richelmi, P., Orrenius, S.: Critical role of sulfhydryl groups in ATP-dependent $\mathrm{Ca}^{2++}$ sequestration by the plasma membrane fraction from rat liver.
FEBS Letter, 163: 136 139, 1983.

4) Nicotera, P., Moore, M., Mirabelli, F., Bellomo, G., Orrenius, S.: Inhibition of hepatocyte plasma membrane $\mathrm{Ca}^{2+-}$-ATPase activity by menadione metabolism and its restoration by thiols. FEBS Letter, 181: 149 153, 1985.

5) Bevan, B.R., Holton, J.B.: Inhibition of bilirubin conjugation in the rat liver slices by free fatty acids with relevance to the problem of breast milk jaundice. Clin. Chim. Acta, 41: 101 107, 1972.

6) Tsien, R.Y.: A non-distruptive technique for loading calcium buffrs and indicators into cells. Nature, 290: 527 528, 1981.

7) Moolenaar, W.H., Tertoolen, L.G.J., DeLaat, S.W.: Growth factors immediatly raise cytoplasmic free $\mathrm{Ca}^{2+}$ in human fibroblasts. J. Biol. Chem., 259: 8066 9069, 1984. 